\title{
A Study of Microstructural Models of Li-doped ZnO Ceramic for Piezoelectric Application
}

\author{
Sunday Ogochukwu Ali ${ }^{1}$, Umaru Ahmadu $^{1^{*} \mathbb{C}}$, Moses Aderemi Olutoye ${ }^{2}$, Oyeleke Olarinoye $^{1}$ \\ ${ }^{1}$ Deparment of Physics, Federal University of Technology, Minna, Nigeria \\ ${ }^{2}$ Department of Chemical Engineering, Federal University of Technology, Minna, Nigeria \\ E-mail: u.ahmadu@ayahoo.com
}

Received: 1 March 2021; Revised: 20 May 2021; Accepted: 20 May 2021

\begin{abstract}
Structural and microstructural properties of $\mathrm{Zn}_{1-\mathrm{x}} \mathrm{Li}_{\mathrm{x}} \mathrm{O}(0.00 \leq x \leq 0.50)$ ceramics were carried out using $\mathrm{X}$-ray Diffraction (XRD) showed that the samples were polycrystalline with hexagonal wurtzite structure. The average crystallite size was estimated using three models, all of which showed decrement with increased lithium-doping. The crystallite size increased systematically, with the largest value being $200 \mathrm{~nm}$ in the $\mathrm{Li}$-doped $\mathrm{ZnO}$ in $\mathrm{x}=0.3$. However, microstrain was fairly constant for all doped samples with a value of $\sim 0.006$, the value for the pristine being 0.001 . Of the three models, the comparison showed that the Scherer model had the smallest crystallite size due to the neglect of strain, whereas the $\mathrm{W}-\mathrm{H}$ model had the largest in the doped samples, with crystallite size $\sim 200 \mathrm{~nm}$, but with subsequent decrease observed which is attributed to the assumption of isotropy in the model. The $c / a$ ratio indicated a consistent hexagonal structure despite lithium-doping. Energy Dispersive Spectroscopy (EDS) showed that all the nominal elements compositions were present. A decrease in grain size with the increase in lithium-doping was observed with the lowest grain size $(0.2 \mu \mathrm{m})$ observed in $\mathrm{x}=0.5$, thus making it the specimen with the highest potential for piezoelectric application.
\end{abstract}

Keywords: sol-gel synthesis, microstructure, crystallite size, X-ray diffraction, elemental analysis

\section{Introduction}

Zinc oxide has the highest piezoelectricity and piezoelectric tensor among tetrahedral semiconductor crystals due to its high electromechanical coupling [1,2]. It is a unique inorganic material that has attracted extensive interest as a result of its characteristic features and novel applications in wide areas of science and technology [3-5]. ZnO belongs to group II-VI compounds. While $\mathrm{Zn}$ is group II, oxygen is in group VI in the periodic table. The bond in $\mathrm{ZnO}$ is largely ionic and explains its strong piezoelectric properties. $\mathrm{ZnO}$ crystallizes in three forms of cubic zinc-blende, cubic Rocksalt, and hexagonal wurtzite crystalline structures. The latter is a stable structure with lattice parameters $a=$ $0.3296 \mathrm{~nm}$ and $c=0.52065 \mathrm{~nm}$. The Wurtzite structure is responsible for the piezoelectric properties exhibited by zinc oxide. Studies have shown that doping zinc oxide with group III elements (Al, In, Ga) leads to the production of high conductive n-type semiconductor [6,7], while doping it with a group I elements ( $\mathrm{Li}, \mathrm{Na}, \mathrm{K})$ leads to the production of high resistive p-type semiconductors [8]. Other structural properties and applications of $\mathrm{ZnO}$ and Li-doped $\mathrm{ZnO}$ have

Copyright (C)2021 Umaru Ahmadu, et al.

DOI: https://doi.org/10.37256/aecm.222021802

This is an open-access article distributed under a CC BY license

(Creative Commons Attribution 4.0 International License)

https://creativecommons.org/licenses/by/4.0/ 
been reported elsewhere [9-12].

Several methods, such as hydrothermal, mechanochemical, precipitation, microwave, sol-gel, amongst others, have been used to prepare doped and pristine Zinc oxide. Also, the determination of the optimum lithium-doping concentration with appropriate grain size which would be most suitable for piezoelectric device application is a possibility through the Sol-gel synthesis technique. This is why this approach was undertaken in the present work to determine the microstructural properties that would be suitable for piezoelectric applications. The Sol-gel method is a chemical solution method that is highly favoured for making ceramics and glass materials in the form of powder, fiber or thin films [13]. Chaari et al. [14] synthesized $\mathrm{ZnO}$ bulk ceramic at various growth temperatures and observed that the alignment of the $\mathrm{ZnO}$ grains along the (100) plane was enhanced as the temperature increased. Ardyanian and Sedigh [15] showed that Li-doped $\mathrm{ZnO}$ has a polycrystalline wurtzite structure with a preferred orientation along the (002) plane, and observed shifts in the diffraction peak angle of $34.57^{\circ} 2 \theta$ in pristine $\mathrm{ZnO}$, among others... bordering on microstructure and structural properties [3, 16-19].

Crystallite size can be determined quantitatively using Debye Scherer, Williamson-Hall and Size-Strain plot methods, each with its limitations and advantages. The Williamson-Hall method relies on the principle that the approximate formulae for crystallite size broadening and strain broadening vary differently with respect to Bragg's angle $\theta$ and is given by:

$$
B_{t o t} \cos \theta=C_{\epsilon} \sin \theta+\frac{k \lambda}{D}
$$

From equation (1), the slope of the plot $B_{\text {tot }} \cos \theta$ against $\sin \theta$ gives the strain in the material $C_{\varepsilon}$, while the intercept gives the size component $\frac{k \lambda}{L}$, where $\beta=$ Full width at half maximum (FWHM) of the diffraction peak expressed in radians, $\theta$ is the Bragg diffraction angle of the XRD peak, $\lambda$ is the wavelength of the X-ray radiation used, which is $1.540598 \AA, \mathrm{D}$ is the crystallite size in nanometers. The Size-strain plot method is used to estimate the size and strain contributions from X-ray line profile analysis using the assumption that the strain profile is explained by Gaussian function while the crystallite size is explained by a Lorentzian function [20]. The merit of this method is that less importance is given to data from reflection at higher angles where the precision is usually lower. Size-strain relation is given by :

$$
(d \beta \cos \theta)^{2}=\frac{K \lambda}{D}\left(d^{2} \beta \cos \theta\right)+\left(\frac{\varepsilon_{a}}{2}\right)^{2}
$$

where $d$ is the interplanar spacing between the atoms, $\beta$ is the full width at half maximum, $\theta$ is the diffracting angle and $\varepsilon_{\mathrm{a}}$ is the apparent microstrain. The apparent microstrain $\varepsilon_{\mathrm{a}}$ is related to the root mean square microstrain by:

$$
\varepsilon_{R M S}=\frac{\varepsilon_{a}}{2 \sqrt{2 \pi}}
$$

The crystallite size calculated using the Debye Scherer formula is:

$$
D=\frac{k \lambda}{\beta \cos \theta}
$$

Or

$$
D=\frac{0.9 \lambda}{\beta \cos \theta}
$$

where $\mathrm{k}$ is the shape factor and varies from $0.89-1.00$. The microstrain can be computed from the slope of the 
Williamson-Hall plot and also using the equation [21]:

$$
\varepsilon=\frac{B}{4 \tan \theta}
$$

In the current work, we examine the Scherer's and Williamson-Hall's models of crystallite size, microstrain analyses based on their different assumptions with specific reference to the size-strain models and understand the physical basis for their differences as they affect the microstructural property, such as grain size, with respect to ZnO application in piezoelectric devices. The results were then situated within the piezoelectric field owing to the varied nature of the application of $\mathrm{ZnO}$, especially within the dopant regime selected for the purpose.

\section{Materials and methods}

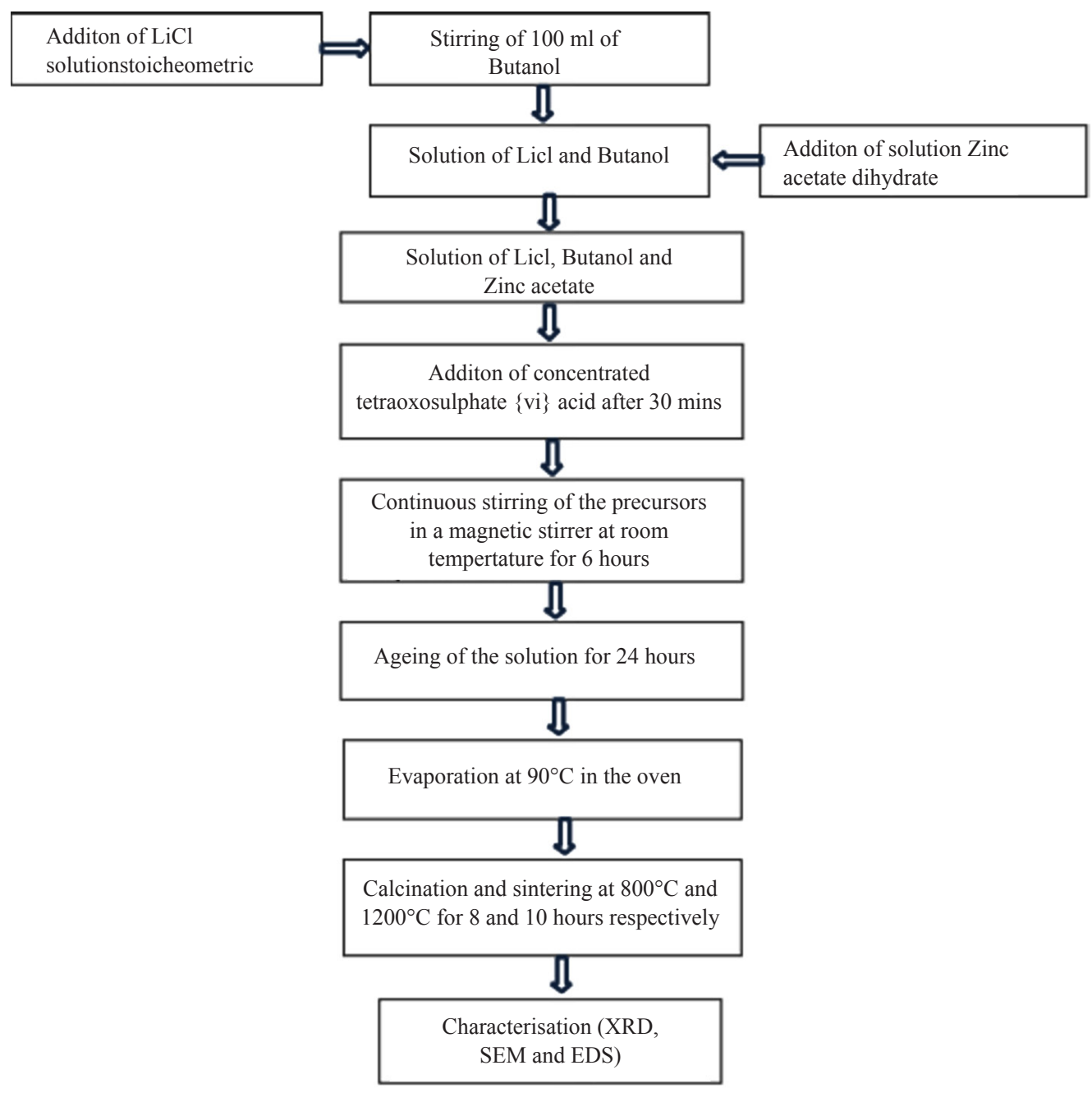

Figure 1. Flow chart for the synthesis of Li-doped and pristine $\mathrm{ZnO}$

The Sol-gel method was used in synthesizing the compositions in this work. The starting materials used were: Zinc acetate dihydrate $\mathrm{Zn}\left(\mathrm{CH}_{3} \mathrm{COO}\right)_{2} \cdot 2 \mathrm{H}_{2} \mathrm{O}$, $\mathrm{LiCl}$ and butanol as a solvent. The compounds $\mathrm{Zn}\left(\mathrm{CH}_{3} \mathrm{COO}\right)_{2} \cdot 2 \mathrm{H}_{2} \mathrm{O}$ and $\mathrm{LiCl}$ were used to synthesize and form the following compositions: $\mathrm{ZnO}, \mathrm{Zn}_{0.7} \mathrm{Li}_{0.3} \mathrm{O}, \mathrm{Zn}_{0.6} \mathrm{Li}_{0.4} \mathrm{O}$ and $\mathrm{Zn}_{0.5} \mathrm{Li}_{0.5} \mathrm{O}$. The 
concentration (mol) of lithium was calculated using equation (7).

All the chemicals used in this synthesis $\left(\mathrm{Zn}\left(\mathrm{CH}_{3} \mathrm{COO}\right)_{2} \cdot 2 \mathrm{H}_{2} \mathrm{O}, \mathrm{LiCl}\right.$ and Butanol) were of analytical grade. The synthesis was carried out by wet chemical reaction, which is also known as the sol-gel technique. Various compositions of the reactants were first weighed using an analytical balance. $100 \mathrm{ml}$ of butanol was measured with a measuring cylinder into a beaker and stirred with a magnetic stirrer. For Li concentration at $\mathrm{x}=0.3$, a solution of lithium chloride was prepared by dissolving $1.228 \mathrm{~g}$ of lithium chloride solute in $50 \mathrm{ml}$ of distilled water. The resulting solution was added gently to $100 \mathrm{ml}$ of butanol and stirred in with a magnetic stirrer. The solution of zinc acetate dihydrate was prepared by dissolving $5.212 \mathrm{~g}$ of zinc acetate dehydrate in $50 \mathrm{ml}$ of butanol. The solution formed was added slowly to the mixture with stirring at room temperature. A drop of concentrated $\mathrm{H}_{2} \mathrm{SO}_{4}$ was added to the mixture after stirring it for 30 min and acted as a stabilizer. The mixture was stirred for six hours in a magnetic stirrer after which it was left to age for 24 hours before evaporation was achieved at a temperature of $90^{\circ} \mathrm{C}$ in an oven. Calcination was used to eliminate volatile materials like water and other impurities at a temperature of $800^{\circ} \mathrm{C}$ for eight hours using a Carbolite RHF 1600 furnace. The sintering of the powder samples was achieved at a temperature of $1200^{\circ} \mathrm{C}$ for ten hours. This process was repeated for other concentrations of lithium. XRD characterisation was carried out for phase identification and analysis. Morphology and microstructural analyses were carried out with High-Resolution Scanning Electron Microscopy (HRSEM). The elemental composition of the prepared samples was confirmed using Energy Dispersive Spectroscopy (EDS). The flow chart of the synthesis process is shown in Figure 1.

\subsection{Calculation of concentration of Lithium}

The concentration of Lithium was calculated using equation (7):

$$
N=\frac{L i_{x(m o l)}}{L i C l} K
$$

where $\mathrm{N}$ is the concentration of Lithium in mol, $\mathrm{K}$ is a multiplication factor having a value of $25 \mathrm{~g}, \mathrm{LiCl}$ is the molecular mass of Lithium Chloride having a value of $42.394 \mathrm{~g} / \mathrm{mol}$ while the molecular mass of Li is $6.941 \mathrm{~g} / \mathrm{mol}$. The calculation of Lithium concentration at

$$
\begin{aligned}
& \mathrm{x}=0.3 \mathrm{~mol}: \frac{0.3(\mathrm{Li})}{\mathrm{LiCl}} \times 25=\frac{0.3 \times 6.941}{42.394} \times 25=\frac{52.0575}{42.394}=1.228 \mathrm{~g} \\
& \mathrm{x}=0.4 \mathrm{~mol}: \frac{0.4(\mathrm{Li})}{\mathrm{LiCl}} \times 25=\frac{0.4 \times 6.941}{42.394} \times 25=\frac{69.41}{42.394}=1.637 \mathrm{~g} \\
& \mathrm{x}=0.5 \mathrm{~mol}: \frac{0.5(\mathrm{Li})}{\mathrm{LiCl}} \times 25=\frac{0.5 \times 6.941}{42.394} \times 25=\frac{86.7625}{42.394}=2.047 \mathrm{~g}
\end{aligned}
$$

\subsection{Calculation of the concentration Zinc}

The concentration of Zinc was calculated using equation (8)

$$
M=\frac{Z n_{1-x(\mathrm{~mol})}}{\mathrm{Zn}(\mathrm{CH} 3 \mathrm{COO})_{2} \cdot 2 \mathrm{H}_{2} \mathrm{O}} K
$$

where $\mathrm{M}$ is the concentration of Zinc in mol, the molecular mass of Zinc is $65.38 \mathrm{~g} / \mathrm{mol}$ while the molecular mass of Zinc acetate dihydrate is $219.53 \mathrm{~g} / \mathrm{mol}$. The concentration of Zinc for 


$$
\begin{aligned}
& \mathrm{x}=0 \mathrm{~mol}: \frac{\mathrm{Zn}}{\mathrm{Zn}(\mathrm{CH} 3 \mathrm{COO})_{2} \cdot 2 \mathrm{H}_{2} \mathrm{O}} \times 25=\frac{65.38}{219.528} \times 25=7.445 \mathrm{~g} \\
& \mathrm{x}=0.3 \mathrm{~mol}: \frac{0.7(\mathrm{Zn})}{\mathrm{Zn}(\mathrm{CH} 3 \mathrm{COO})_{2} \cdot 2 \mathrm{H}_{2} \mathrm{O}} \times 25=\frac{0.7 \times 65.38}{219.528} \times 25=\frac{1144.15}{219.528}=5.212 \mathrm{~g} \\
& \mathrm{x}=0.4 \mathrm{~mol}: \frac{0.6(\mathrm{Zn})}{\mathrm{Zn}(\mathrm{CH} 3 \mathrm{COO})_{2} \cdot 2 \mathrm{H}_{2} \mathrm{O}} \times 25=\frac{0.6 \times 65.38}{219.528} \times 25=\frac{980.7}{219.528}=4.467 \mathrm{~g} \\
& \mathrm{x}=0.5 \mathrm{~mol}: \frac{0.5(\mathrm{Zn})}{\mathrm{Zn}(\mathrm{CH} 3 \mathrm{COO})_{2} \cdot 2 \mathrm{H}_{2} \mathrm{O}} \times 25=\frac{0.5 \times 65.38}{219.528} \times 25=\frac{817.25}{219.528}=3.723 \mathrm{~g}
\end{aligned}
$$

\section{Results and discussion}

The XRD pattern of the synthesized $\mathrm{Zn}_{1-\mathrm{x}} \mathrm{Li}_{\mathrm{x}} \mathrm{O}(0.00 \leq x \leq 0.50)$ is depicted in Figure 2. The patterns confirmed that the prepared ceramics are polycrystalline with a single-phase wurtzite hexagonal structure which is in agreement with the reference pattern of a Joint Committee on Powder Diffraction Standard (JCPDS) data card (ID-36-1451), see supplementary material. The patterns are also in agreement with the reports of other workers who prepared lithium doped zinc oxide using a similar method [15, 22-24].

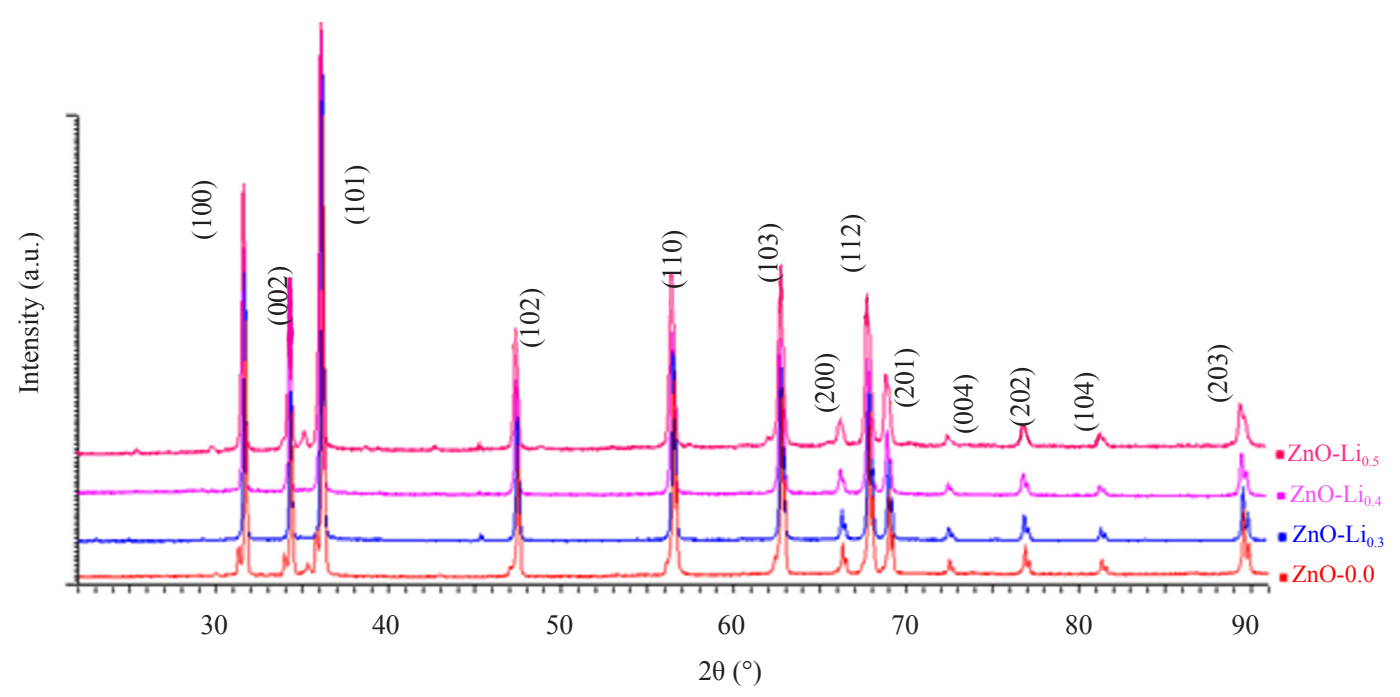

Figure 2. X-ray diffraction pattern of $\mathrm{Zn}_{1-\mathrm{x}} \mathrm{Li}_{\mathrm{x}} \mathrm{O}(0.00 \leq x \leq 0.50)$ ceramics at diffraction angular range of $20^{\circ} \leq 2 \theta \leq 90^{\circ}$ (a) pristine Zinc Oxide ( $\mathrm{x}=0.00)(\mathrm{b}) \mathrm{x}=0.3$ (c) $\mathrm{x}=0.4$ and (d) $\mathrm{x}=0.5$

The phases remained unchanged with an increase in dopant concentration from as shown in Figure 2 (a-d). The strongest peaks occur at (100), (002), (101), (102), (110), (103), (112), (201) and (203) reflection planes. By doping $\mathrm{ZnO}$ with lithium, the lithium atoms occupied the $\mathrm{Zn}$ sites in the $\mathrm{ZnO}$ lattice due to their comparable ionic radii [25]. It was observed that the intensity of the (101), (102) and (110) peaks increased as a result of lithium doping at the concentration of $x=0.3$. As the doping concentration of lithium increased, the intensity of (100), (002) and (200) decreased consistently. This is due to the substitution of $\mathrm{Li}^{+}$ions with a smaller ionic radius $(0.68 \AA)$ with $\mathrm{Zn}^{2+}$ ions with a larger ionic radius $(0.74 \AA)$. A similar result had been reported [19] by other workers. Table 1 shows the hkl, $2 \theta$ 
positions, amongst others, extracted from the XRD data.

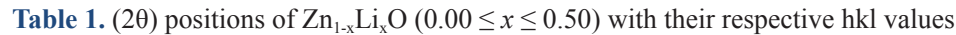

\begin{tabular}{|c|c|c|c|c|c|}
\hline $\mathrm{S} / \mathrm{n}$ & hkl & $\begin{array}{l}\mathrm{ZnO} \\
2 \theta\left(^{\circ}\right)\end{array}$ & $\begin{array}{c}\mathrm{Zn}_{0.7} \mathrm{Li}_{0.3} \mathrm{O} \\
2 \theta\left(^{\circ}\right)\end{array}$ & $\begin{array}{c}\mathrm{Zn}_{0.6} \mathrm{Li}_{0.4} \mathrm{O} \\
2 \theta\left(^{\circ}\right)\end{array}$ & $\begin{array}{c}\mathrm{Zn}_{0.5} \mathrm{Li}_{0.5} \mathrm{O} \\
2 \theta\left({ }^{\circ}\right)\end{array}$ \\
\hline 1 & 100 & 31.7075 & 31.7418 & 31.7075 & 31.8447 \\
\hline 2 & 002 & 34.383 & 34.383 & 34.383 & 34.4173 \\
\hline 3 & 101 & 36.201 & 36.201 & 36.1667 & 36.1324 \\
\hline 4 & 102 & 47.4864 & 47.4521 & 47.5207 & 47.5893 \\
\hline 5 & 110 & 56.5078 & 56.5421 & 56.5078 & 56.5764 \\
\hline 6 & 103 & 62.8194 & 62.7851 & 62.8191 & 62.8194 \\
\hline 7 & 201 & 68.9937 & 67.8275 & 68.9937 & 68.9937 \\
\hline 8 & 004 & 72.4239 & 72.5268 & 72.3896 & 72.2867 \\
\hline 9 & 202 & 76.8832 & 76.8489 & 76.8832 & 76.8146 \\
\hline 10 & 104 & 81.3082 & 80.0047 & 81.3425 & 81.3082 \\
\hline 11 & 203 & 89.5063 & 89.5063 & 89.4720 & 89.5063 \\
\hline
\end{tabular}

It was observed that the peak positions, in some cases, shifted to lower and higher angles as a result of lithium doping, in agreement with an earlier report [26]. The shifting to higher and lower angles is shown in the supplementary materials section in which those of $\mathrm{x}=0.00$ and $\mathrm{x}=0.40$ shifted to lower angles, while those of $\mathrm{x}=0.30$ and 0.50 shifted to higher angles. The shift to higher angles is an indication of the decrease in lattice parameters due to the replacement of smaller $\mathrm{Li}^{+}$ions at $\mathrm{Zn}^{2+}$ sites and to the broadening of the peak positions as a result of lithium doping. Some workers $[18,27]$ have attributed the dual shift to competition between compressive stress and tensile stress in the lattice structure as a result of the substitution of Li atoms at the interstices and $\mathrm{Zn}$ sites, respectively. The incorporation of Lithium atoms in the interstice and lattice site of $\mathrm{ZnO}$ could also lead to the segregation of insoluble $\mathrm{Li}$ atoms at the grain boundaries thereby suppressing the growth of $\mathrm{Zn}_{1-x} \mathrm{Li}_{x} \mathrm{O}$ [28] grains.

\subsection{Estimation of the crystallite size and microstrain}

The average crystallite size(s) and microstrain were calculated using the Scherer equation, Williamson-Hall (WH) and Size-Strain (S-S) analyses, respectively. In the Scherer model, the average crystallite size(s) was estimated using the most prominent peak (101). The result for the Scherer crystallite size is presented in Figure 3 and shows clearly that the crystallite size decreased as a result of the increase in FWHM with dopant concentration. This is attributed to $\mathrm{Li}^{+}$ ions with small ionic sizes having replaced the $\mathrm{Zn}^{2+}$ ions with larger ionic sizes. The decrease in crystallite size with dopant concentration has been attributed to the observed deterioration in the crystallinity of the samples [16] as shown in Figure 3. 


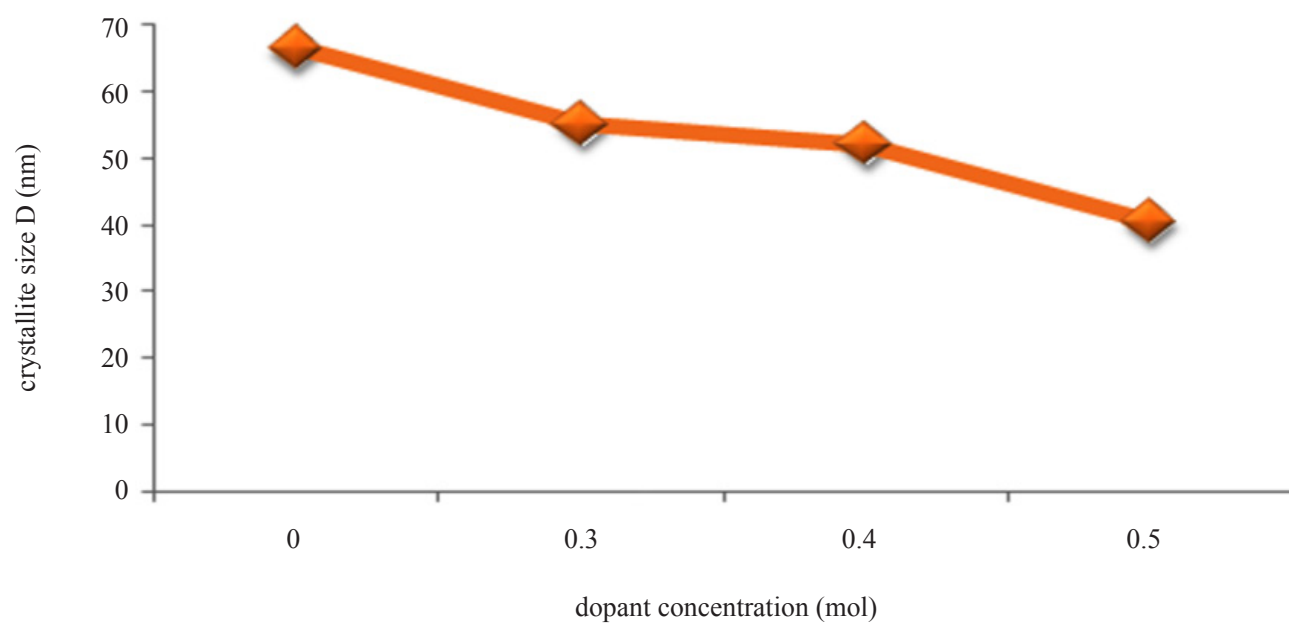

Figure 3. Variation in crystallite size with lithium concentration for the most prominent peak (101)

The average crystallite size of the pristine zinc oxide was calculated as $66.56 \mathrm{~nm}$. As the dopant concentration increased, there is a systemic decrease in the crystallite sizes from 66.56, 52.02, 52.13 and $40.54 \mathrm{~nm}$, respectively, and is evidence of the fact that the incorporation of lithium atoms inhibits the growth of $\mathrm{ZnO}$ crystallites [24]. Table 2 shows the summary of Full Width at Half Maximum (FWHM), $2 \theta$ positions and the Scherer crystallite size for the (101) plane.

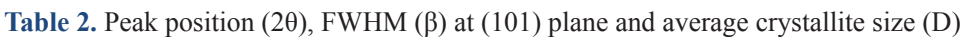

\begin{tabular}{cccc}
\hline Sample & $2 \theta$ (degree) & $\beta \times 10^{-3}$ (radians) & $\mathrm{D}(\mathrm{nm})$ \\
\hline $\mathrm{ZnO}$ & 36.201 & 2.19 & 66.50 \\
$\mathrm{Zn}_{0.7} \mathrm{Li}_{0.3} \mathrm{O}$ & 36.235 & 2.64 & 55.02 \\
$\mathrm{Zn}_{0.6} \mathrm{Li}_{0.4} \mathrm{O}$ & 36.201 & 2.80 & 52.13 \\
$\mathrm{Zn}_{0.5} \mathrm{Li}_{0.5} \mathrm{O}$ & 36.270 & 3.60 & 40.54 \\
\hline
\end{tabular}

Table 2 shows that the FWHM increased consistently as a result of broadening of the diffraction peak, consequently, the Scherer crystallite size decreased consistently with lithium doping.

\subsection{Williamson-Hall (W-H) analysis of the crystallite size and strain}

Though XRD peak intensities can be used to estimate the crystallite size using the Debye-Scherer equation (Eqn. 5), it is limited because it does not account for the strain in the prepared samples. There are several methods reported in the literature that have been used to estimate the crystallite size and lattice strain, such as Warren-Averbach and Rietveld refinement. However, the Williamson-Hall (W-H) is a simplified integral breadth method employed for estimating the crystallite size and lattice strain, thereby accounting for the strain in the samples. The W-H crystallite size is attributed to diffraction line broadening due to the contributions of the crystallite size and lattice strain. The unique nature of the W-H method is that it differentiates clearly between crystallite size and lattice strain peak broadening by considering the peak width as a function of $2 \theta$ [29]. Note that the size obtained is direction-dependent in this method. 

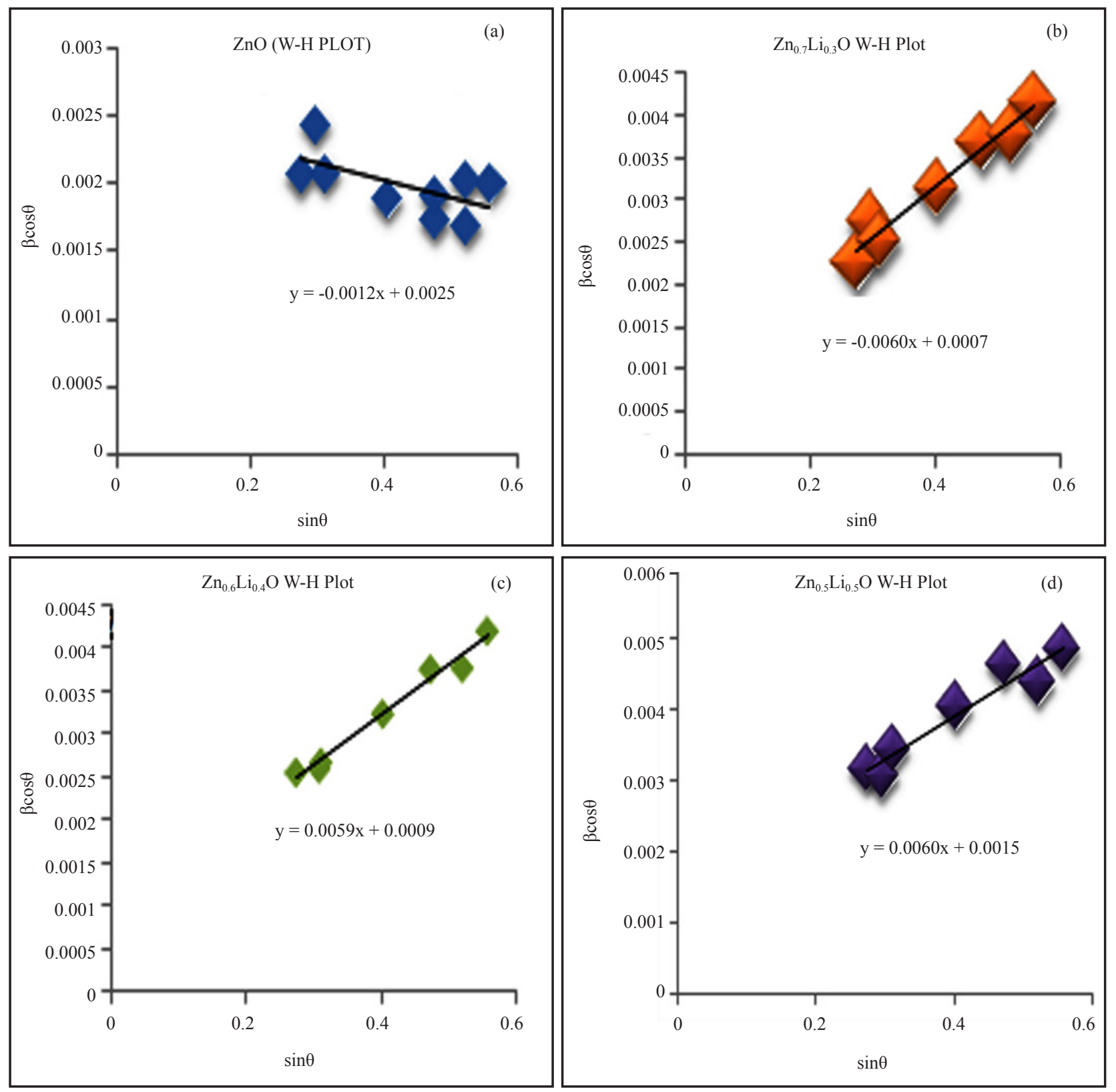

Figure 4. Williamson-Hall plot for all the samples (a) undoped $\mathrm{ZnO}$ (b) $\mathrm{Zn}_{0.7} \mathrm{Li}_{0.3} \mathrm{O}$ (c) $\mathrm{Zn}_{0.6} \mathrm{Li}_{0.4} \mathrm{O}$ and (d) $\mathrm{Zn}_{0.5} \mathrm{Li}_{0.5} \mathrm{O}$

Lattice stain-induced peak broadening is due to powder crystal imperfections and lattice distortions. The W-H equation given in Eqn. (2) assumes that strain in the prepared samples is uniform in all crystallographic directions based on the assumption that the crystal is isotropic in nature and that the properties of materials are independent of the direction of measurement [30]. The values of $\beta \cos \theta$ on $y$-axis were plotted as a function of $\sin \theta$ on the $x$-axis as shown in Figure 4, while the crystallite size D, which was estimated from the y-intercept, and the microstrain $\varepsilon$ were obtained from the slope of the graphs of the linear plot as shown in Figure 5. 


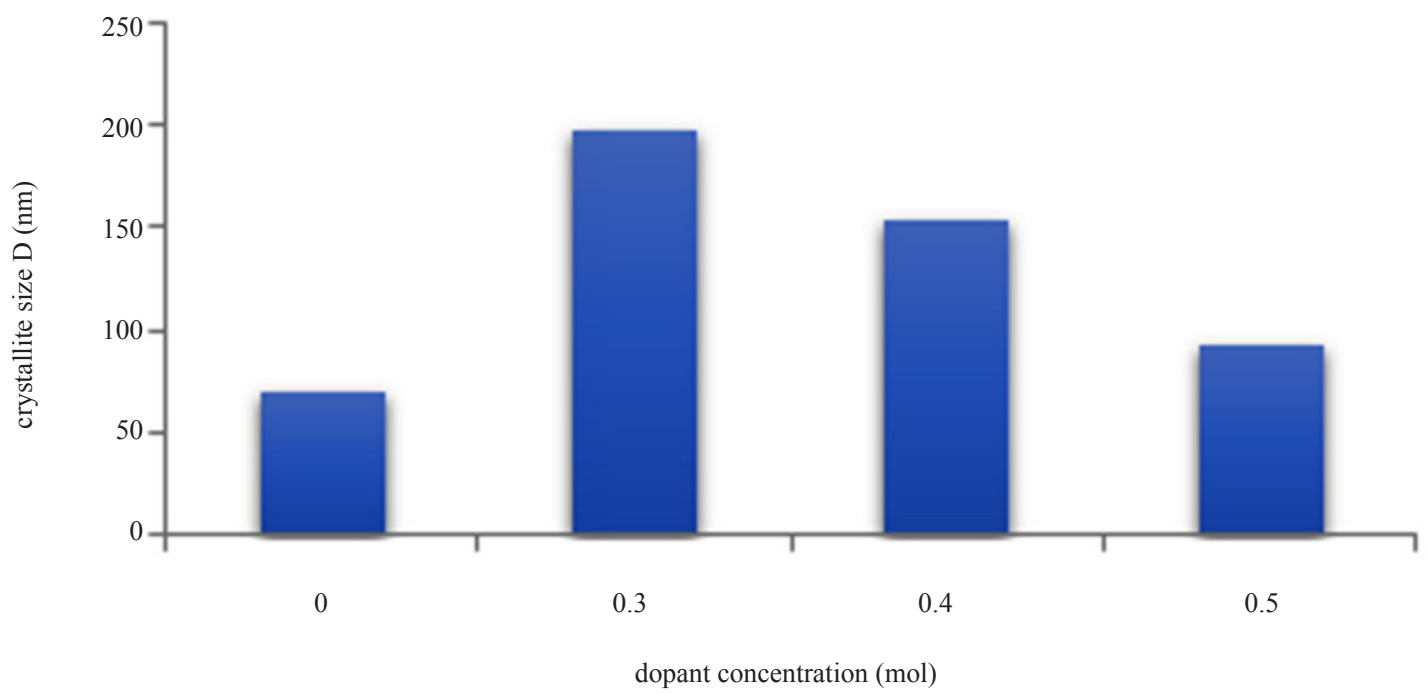

Figure 5. Composite W-H crystallite size with dopant concentration

The crystallite size is seen to increase considerably in the lithium-doped zinc oxide as compared to pristine zinc oxide and then decreased systematically with an increase in lithium concentration. This is attributed to the introduction of strain in the doped zinc oxide. Figure 6 is a graph of lattice strain and dopant concentration. The observed microstrain in the prepared samples was fairly constant and may be due to lattice mismatch as was observed in the lattice parameters.

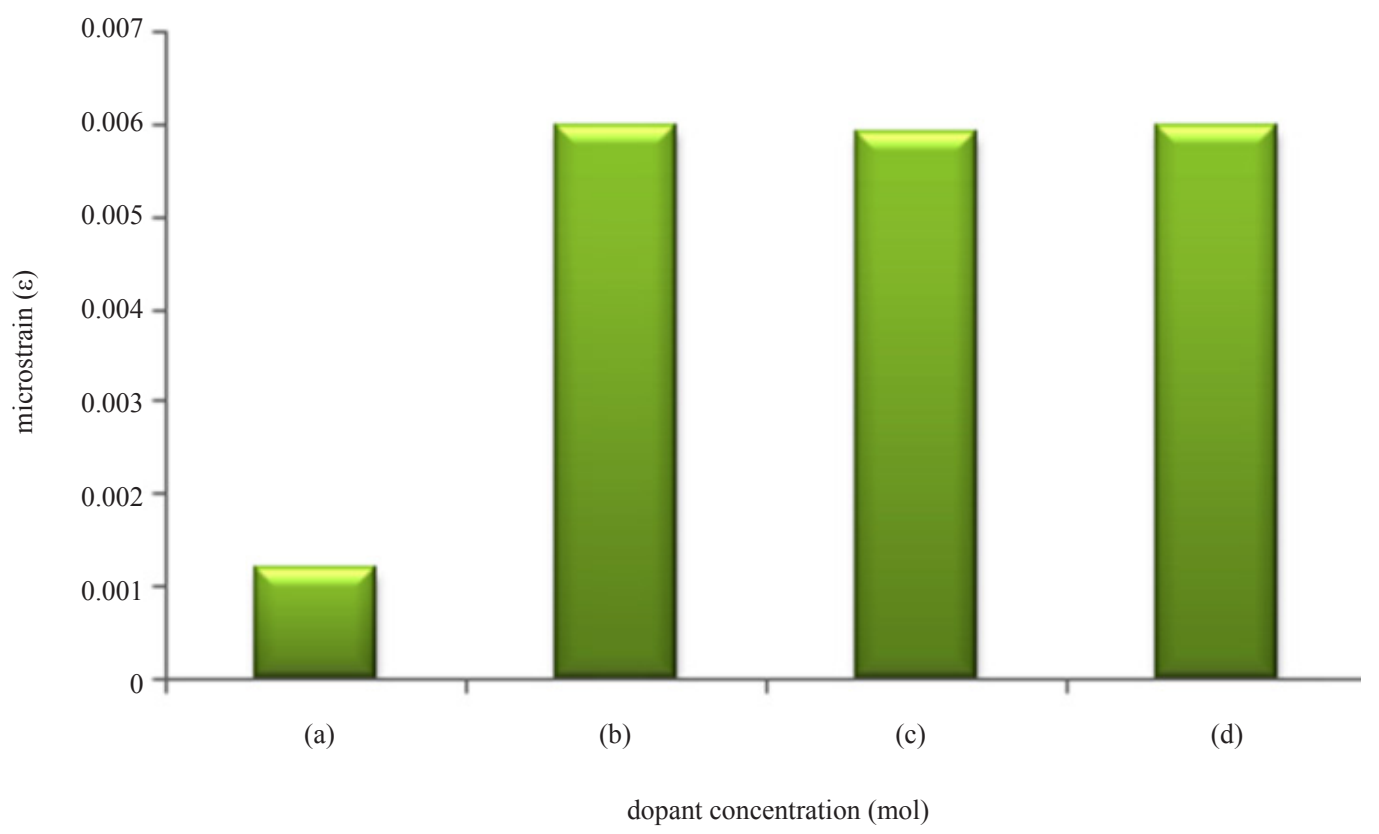

Figure 6. Variation of $\mathrm{W}-\mathrm{H}$ microstrain with dopant concentration (a) pristine $\mathrm{ZnO} \mathrm{x}=0.0$ (b) $\mathrm{Zn}_{0.7} \mathrm{Li}_{0.3} \mathrm{O} x=0.3$ (c) $\mathrm{Zn}_{0.6} \mathrm{Li}_{0.4} \mathrm{O} x=0.4$ and (d) $\mathrm{Zn}_{0.5} \mathrm{Li}_{0.5} \mathrm{O} x=0.5$

Size-Strain plot has been reported as a better technique for the estimation of the crystallite size and strain in 
samples because it pays less importance to data at high angles of reflection and the data points lie very close to the linear fit. The Size-Strain equation is shown in Eqn. (2). The crystallite size is calculated from the gradient of the linear fit and the apparent strain computed from the intercept of the linear fit. The various size-strain plots are shown in the supplementary materials section. The crystallite sizes computed from these models show a systematic decrease with an increase in dopant concentration and follow the same trend as those of the W-H and Scherer models. Figure 7 shows the composite crystallite size plot with dopant concentration for the three models for comparison.

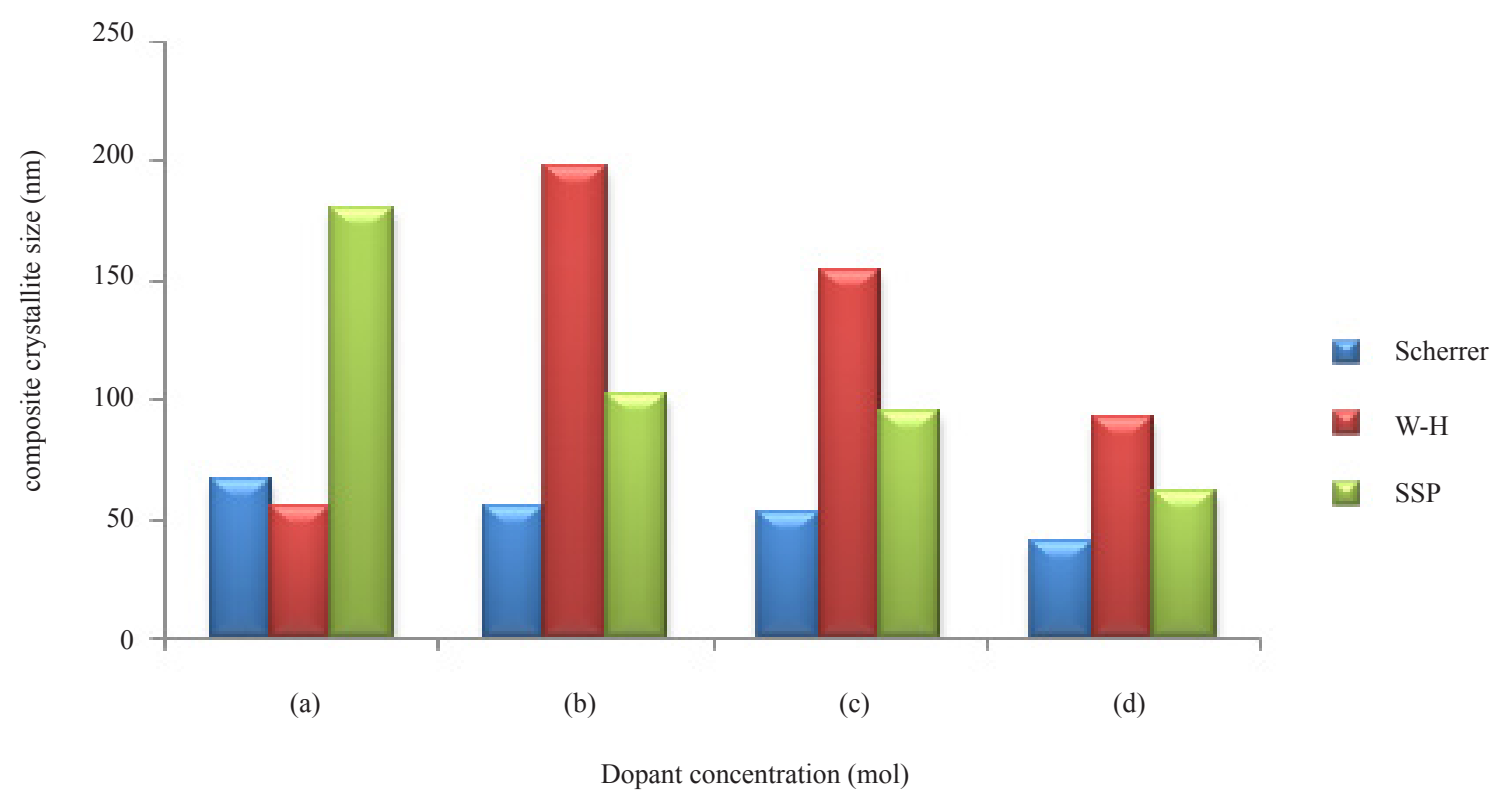

Figure 7. Composite plot of variation of crystallite size with dopant concentration (a) $\mathrm{ZnO} \mathrm{x}=0.0$, (b) $\mathrm{Zn}_{0.7} \mathrm{Li}_{0.3} \mathrm{O} x=0.3$ (c) $\mathrm{Zn}_{0.6} \mathrm{Li}_{0.4} \mathrm{O} x=0.4$ and (d) $\mathrm{Zn}_{0.5} \mathrm{Li}_{0.5} \mathrm{O} x=0.5$

Scherer's equation with the (101) plane, the W-H and the Size-strain plots were plotted. The computed crystallite size(s) followed the same trend with the Scherer crystallite size being smaller than the others due to the neglect of microstrain contribution to peak broadening [31]. On the other hand, it is observed that Size-strain crystallite size decreased systematically and varied with the W-H analysis at $\mathrm{x}=0.0$. This discrepancy could be attributed to the assumption of isotropy in the W-H model.

\subsection{Lattice parameters}

In Table 3, the results of the computed lattice parameters have been presented. The lattice parameter $a$ decreased from $3.256 \AA$ to $3.243 \AA$, while $c$ decreased from $5.640 \AA$ to $5.620 \AA$. The values are in close agreement with the standard JCPDS card for zinc oxide. The $c / a$ ratio was constant up to the fourth decimal place, showing that zinc oxide maintained its hexagonal wurtzite structure in spite of doping. A decrease in lattice parameters with an increase in lithium doping should be expected when $\mathrm{Zn}^{2+}$ ions are substituted by $\mathrm{Li}^{+}$ions owing to the smaller ionic radius $(0.068$ $\AA$ ) of $\mathrm{Li}^{+}$ions compared to that of $\mathrm{Zn}^{2+}$ ions $(0.074 \AA)$. Other researchers have reported similar results [32, 33], though Khalid et al. [34] attributed it to the presence of zinc vacancies.

The unit cell volumes also followed similar trends as the lattice parameters, decreasing from 51.77 to $51.15 \AA^{3}$ with lithium incorporation, which is similarly attributed to the ionic difference between the dopant and the host atom. The bond lengths also decreased with an increase in lithium dopant. 
Table 3. Typical computed lattice constants, c/a ratio, unit cell volume, d-spacing and bond length ( $\mathrm{L}$ ) for $\mathrm{Zn}_{1-\mathrm{x}} \mathrm{Li}_{\mathrm{x}} \mathrm{O}(0.00 \leq x \leq 0.50)$ at $(100)$ plane

\begin{tabular}{ccccccc}
\hline Sample & $\mathrm{a}(\AA)$ & $\mathrm{c}(\AA)$ & $c / a$ & $\begin{array}{c}\text { Cell volume } \\
\left(\AA^{3}\right)\end{array}$ & $\mathrm{d}(\AA)$ & $\begin{array}{c}\mathrm{Zn}-\mathrm{O} \\
\mathrm{L}(\AA)\end{array}$ \\
\hline Reference $\mathrm{ZnO}$ & 3.2498 & 5.2066 & 1.6021 & 47.62 & - & 1.992 \\
$\mathrm{ZnO}$ & 3.2560 & 5.6391 & 1.73191 & 51.77 & 2.8195 & 2.036445 \\
$\mathrm{Zn}_{0.7} \mathrm{Li}_{0.3} \mathrm{O}$ & 3.2524 & 5.6329 & 1.73192 & 51.61 & 2.8164 & 2.03421 \\
$\mathrm{Zn}_{0.6} \mathrm{Li}_{0.4} \mathrm{O}$ & 3.2560 & 5.6391 & 1.73191 & 51.77 & 2.8198 & 2.036444 \\
$\mathrm{Zn}_{0.5} \mathrm{Li}_{0.5} \mathrm{O}$ & 3.2429 & 5.6165 & 1.73194 & 51.15 & 2.8082 & 1.877461 \\
\hline
\end{tabular}

\subsection{High-Resolution Scanning Electron Microscopy}
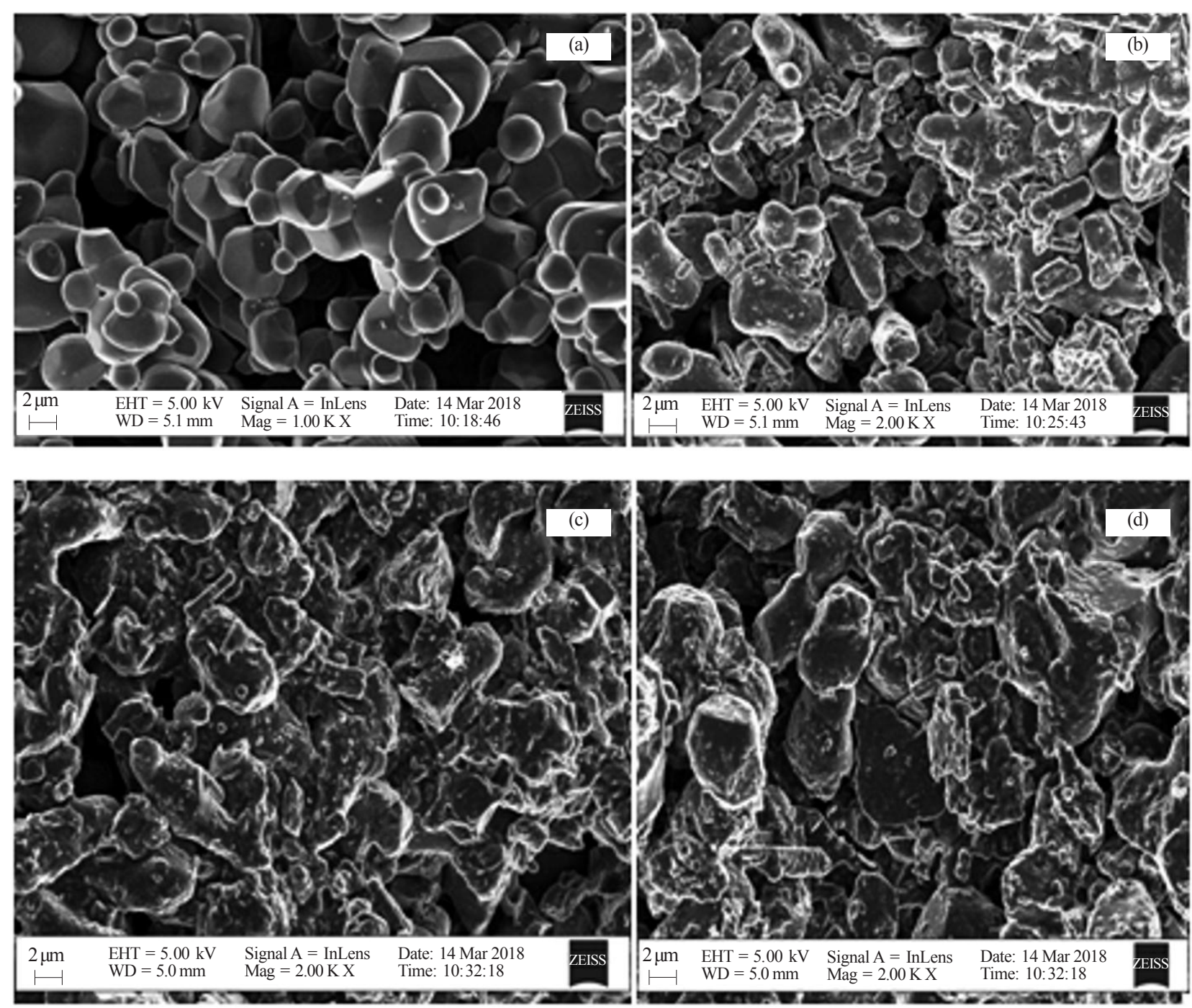

Figure 8. HRSEM images of $\mathrm{Zn}_{1-x} \mathrm{Li}_{\mathrm{x}} \mathrm{O}$ for different $\mathrm{Li}$ concentrations at the magnification of $\mathrm{x} 2000$.

(a) $\mathrm{x}=0.0$ with spherical grains and porous regions (b) $\mathrm{x}=0.30$ has rod-like grains and some porous regions

(c) $\mathrm{X}=0.40$ has rod-like grains and larger agglomeration of smaller grains while (d) $\mathrm{x}=0.50$ has rod-like grains 
The morphology of the synthesized doped and undoped zinc oxide was determined using Auriga Field Emission High-Resolution Scanning Electron Microscopy (HRSEM). The micrographs are shown in Figure 8.

The HRSEM results clearly showed that the morphology and the grain size(s) of lithium-doped and pristine zinc oxide vary with respect to dopant concentration. It can be concluded that the morphology of pristine zinc oxide is spherical in shape but evolved to a rod-like shape with an increase in doping. At $x=0.5$ for example, the micrographs reveal a more uniform distribution of grains and a high degree of agglomeration of smaller particles.

The average grain size of the pristine zinc oxide is $1.23 \mu \mathrm{m}$, while those of the lithium-doped zinc oxide are 0.28 $\mu \mathrm{m}, 0.22 \mu \mathrm{m}$ and $0.14 \mu \mathrm{m}$, respectively fro $\mathrm{x}=0.3,0.4$ and 0.5 . Hence, there is a general decrease in grain size as a result of doping with lithium (Figure 9). The incorporation of lithium inhibits the rate of grain growth [24], while the electrical properties of materials depend strongly on grain sizes [35], grain boundaries and defects present. Therefore, doping can alter the grain size and increase or decrease electrical properties. An increase in grain size reduces trapping of charged carries at the grain boundaries and also decreases the grain boundary density, thereby increasing the electrical conductivity of the material [36]; whereas a decrease in grain size increases the trapping and scattering of charged carries at the grain boundaries. Thus, the observed decrease in grain size is expected to increase the resistivity of the lithium-doped zinc oxide since the $\mathrm{Li}^{+}$ions act as acceptors, thereby reducing the charge carrier at the grain boundaries [37] resulting in an increase in resistivity of the material [32]. Materials with high resistivity are promising candidates for piezoelectric applications. David and Hsu [37] have established the relationship between piezoelectricity and resistivity in their work in which resistivity varied directly with piezoelectric properties in zinc oxide. Figure 9 (a-d) shows the composite histogram of the average grain size computed using Image $\mathrm{J}$ software for different samples.

The results show that Figure 9 (a \& d) has more uniform grain distributions compared to Figure 10 (b \& c) which has more non-uniform grain distributions. On the other hand, Figure 9 (c \& d) shows wider grain distribution. The computed grain sizes from the histogram are shown in Figure 10.

Figure 10 is the plot of the average grain size vs. dopant concentration and shows that pristine $\mathrm{ZnO}$ has the highest grain size. Li-doped $\mathrm{ZnO}$ at the concentration $\mathrm{x}=0.5$ has the least grain size. Moreover, it is observed that the grain size decreased monotonically with an increase in lithium doping, implying that incorporation of lithium inhibited the growth of the grains [24].

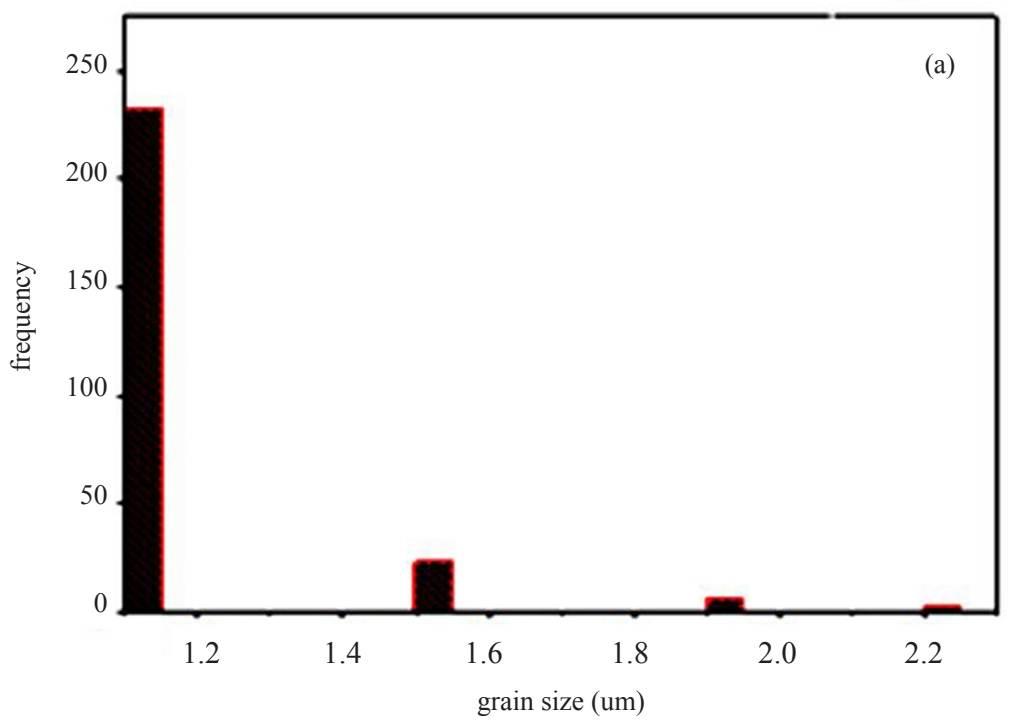



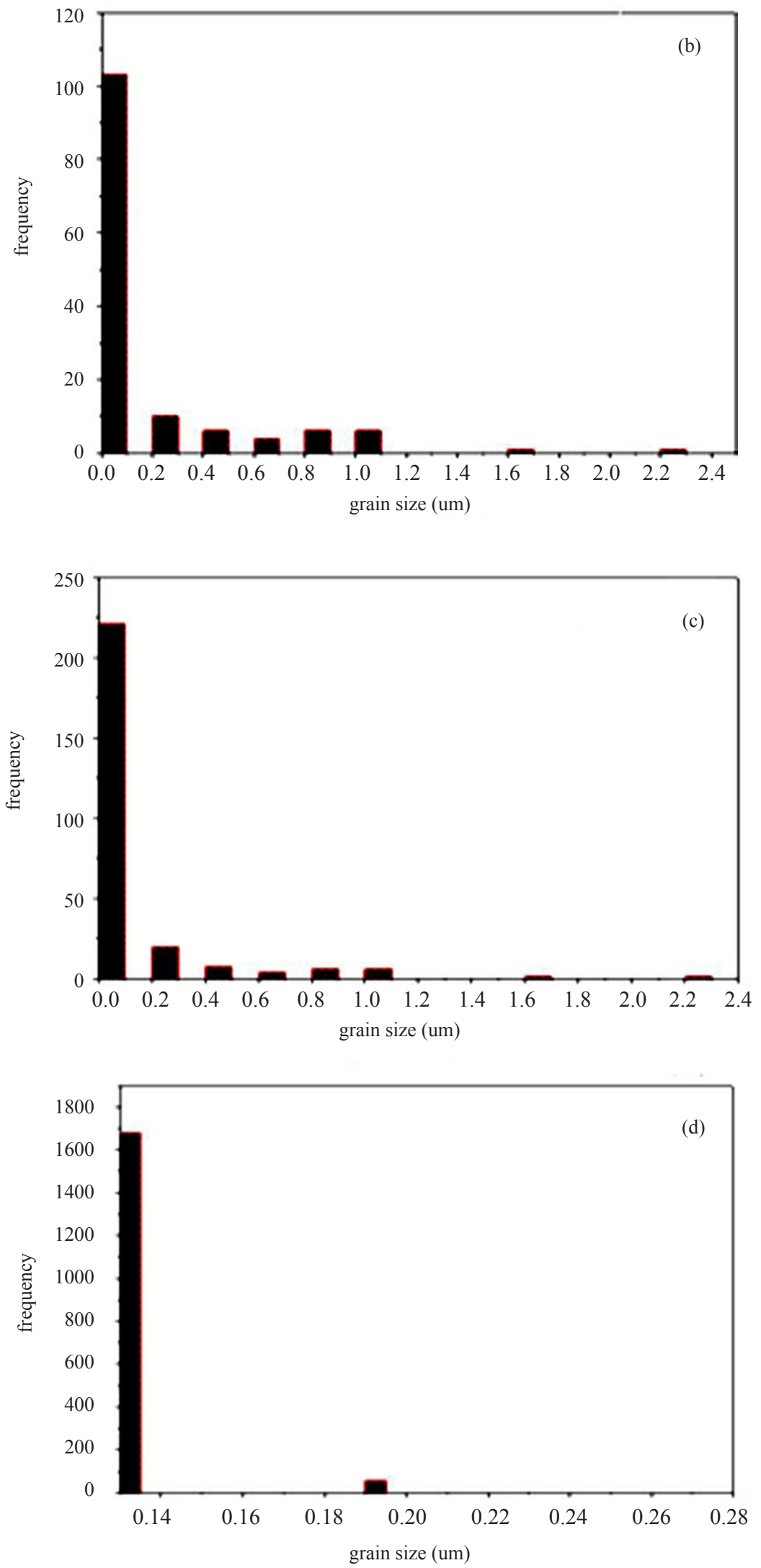

Figure 9. Grain size histogram plot (a) $x=0.00$ shows non-uniform grain $(b) x=0.3$ shows more non-uniform grain distribution (c) $\mathrm{x}=0.4$ follows the same trend as $\mathrm{x}=0.3$ and (d) $\mathrm{x}=0.5$ shows even less uniform grain distribution 


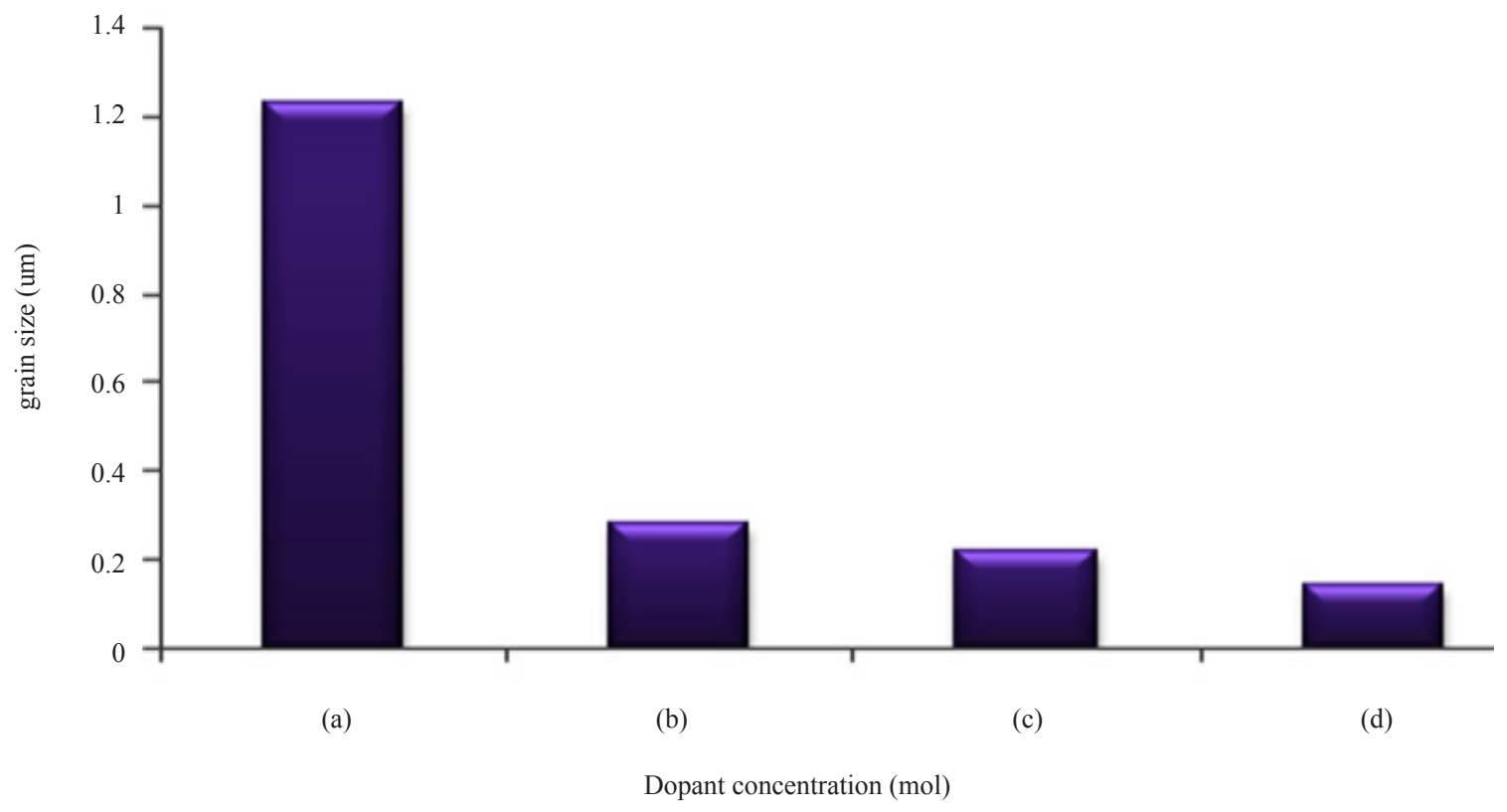

Figure 10. Composite grain size plot (a) $\mathrm{x}=0.00$, grain size $=1.23 \mu \mathrm{m}$ (b) $\mathrm{x}=0.3$, grain size $=0.28 \mu \mathrm{m}(\mathrm{c}) \mathrm{x}=0.4$, grain size $=0.22 \mu \mathrm{m}$ and $(\mathrm{d}) \mathrm{x}=0.5$, grain size $=0.14 \mu \mathrm{m}$

\subsection{Chemical composition}

Figure 11 is the Energy Dispersive Spectroscopy (EDS) results of the samples for the synthesized $\mathrm{Zn}_{1-\mathrm{x}} \mathrm{Li}_{\mathrm{x}} \mathrm{O}$ ceramics. The spectra clearly revealed the presence of $\mathrm{Zn}$ and O. However, Li was not detected because of its low atomic number and small concentration. The EDS machine can only detect atoms with atomic numbers beyond 5 (Boron). The spectrum shows the presence of other elements such as carbon, iron, silicon, chlorine and calcium. Carbon was used as sample holder and catalyst during the SEM analysis, however, the source of the other elements requires further investigation, even though they have very low peaks implying that their concentrations a very low as well.

The EDS result gives credence to the other characterisation results for both pristine and lithium-doped zinc oxide. Table 4 shows the quantitative analysis of the EDS-derived elemental composition.

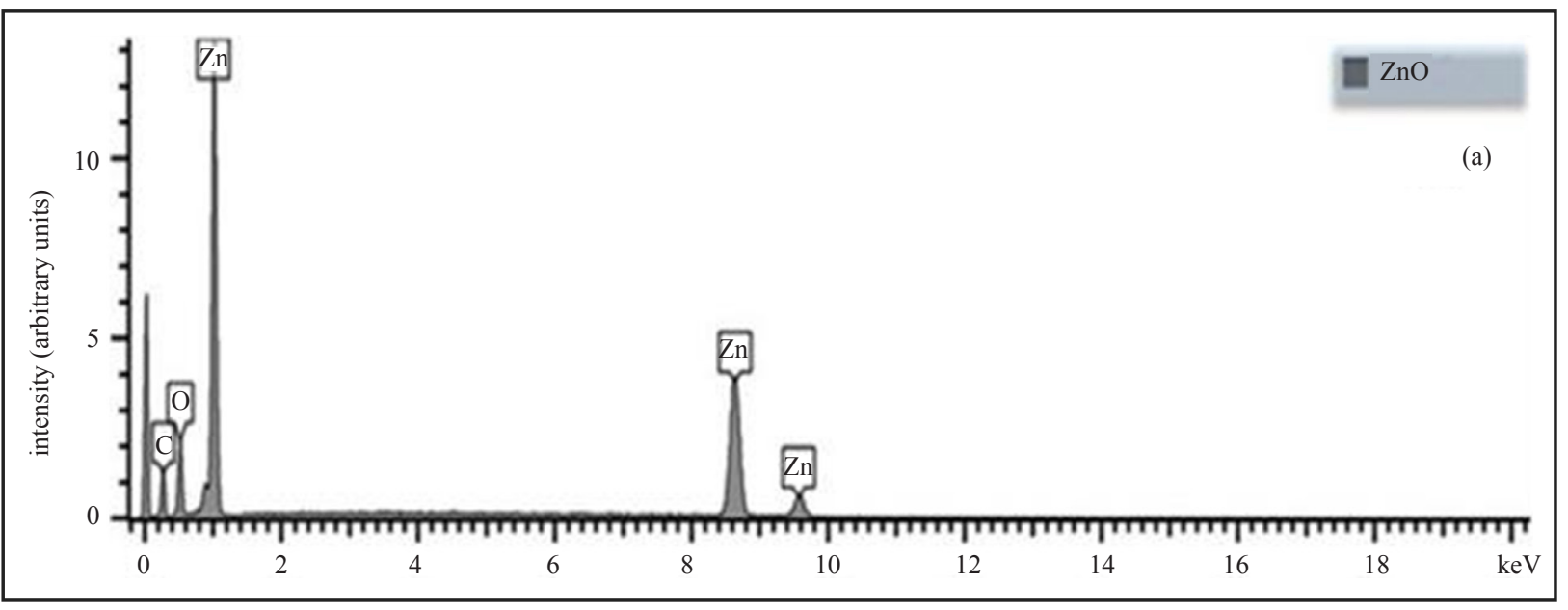



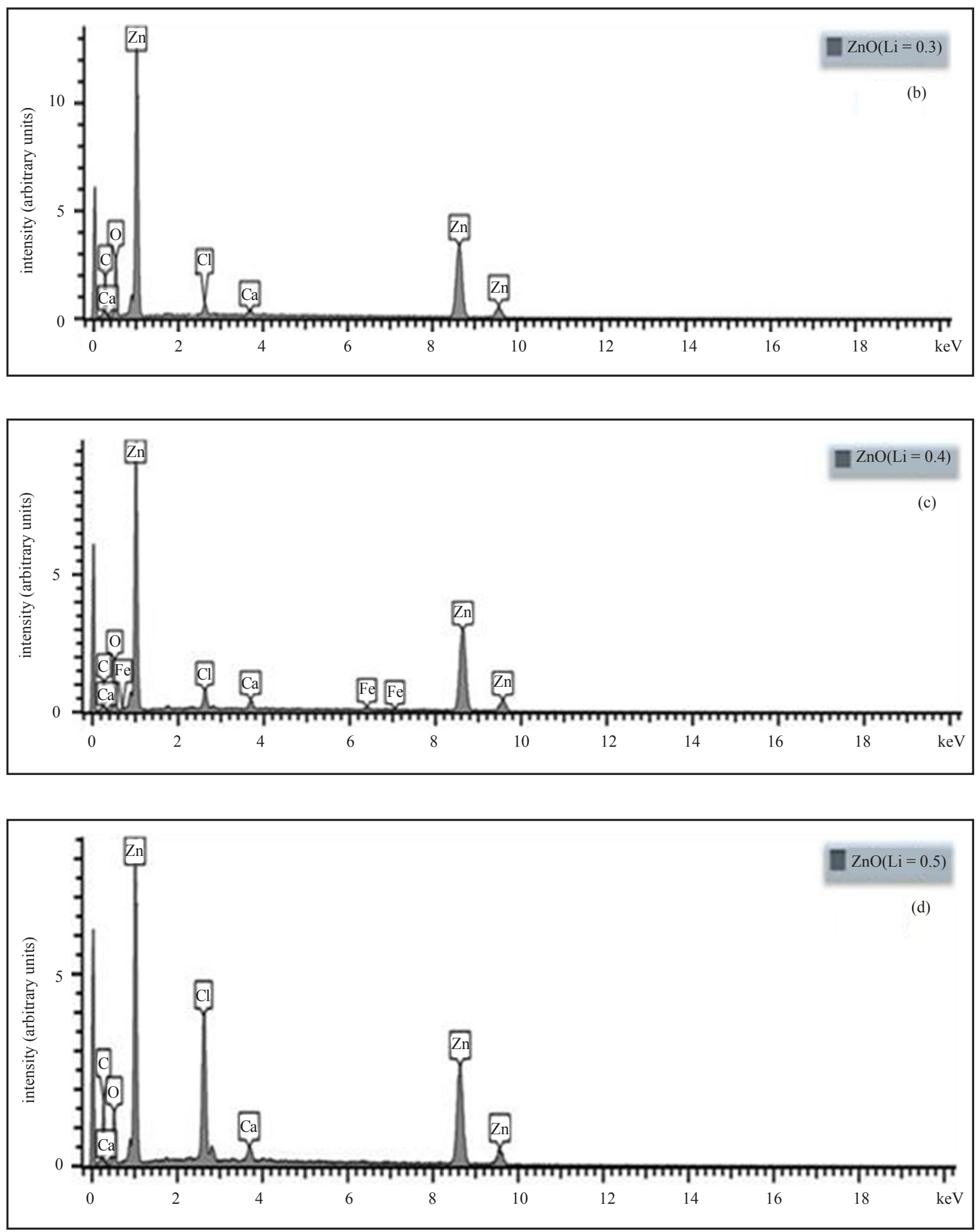

Figure 11. EDS spectrum of (a) $\mathrm{x}=0.00$ with $\mathrm{Zn}, \mathrm{O}, \mathrm{C}$ (b) $\mathrm{x}=0.30$ with $\mathrm{Zn}, \mathrm{O}, \mathrm{C}, \mathrm{Ca}$ and $\mathrm{Cl}$ (c) $\mathrm{x}=0.4$ with $\mathrm{Zn}, \mathrm{O}, \mathrm{C}, \mathrm{Fe}, \mathrm{Ca}$ and (d) $\mathrm{x}=0.50$ with $\mathrm{Zn}, \mathrm{O}, \mathrm{C}, \mathrm{Fe}, \mathrm{Ca}$ and $\mathrm{Cl}$. $\mathrm{Li}$ is not shown in the spectrum because of the detection limit of EDS 
Table 4. Norminal elemental composition of EDS

\begin{tabular}{|c|c|c|c|c|c|c|c|c|}
\hline \multicolumn{9}{|c|}{ Normalised ESD derived composition (atomic \%) } \\
\hline Sample & $\mathrm{Zn}$ & $\mathrm{C}$ & $\mathrm{O}$ & $\mathrm{Ca}$ & $\mathrm{Cl}$ & $\mathrm{Si}$ & $\mathrm{Fe}$ & Total \\
\hline 0.00 & 31.44 & 54.81 & 13.75 & - & - & - & - & 100.00 \\
\hline 0.30 & 22.76 & 56.56 & 18.95 & 0.38 & 0.66 & 0.69 & - & 100.00 \\
\hline 0.40 & 25.34 & 50.63 & 19.80 & 0.90 & 1.62 & 0.61 & 1.10 & 100.00 \\
\hline 0.50 & 25.04 & 59.13 & 11.81 & 0.22 & 3.23 & 0.20 & 0.37 & 100.00 \\
\hline
\end{tabular}

Table 4 shows the presence of $\mathrm{Zn}, \mathrm{O}, \mathrm{C}$ and other elements such as $\mathrm{Ca}, \mathrm{Cl}, \mathrm{Si}$ and $\mathrm{Fe}$ in very low concentrations.

\section{Conclusion}

$\mathrm{Zn}_{1-\mathrm{x}} \mathrm{Li}_{\mathrm{x}} \mathrm{O}(0.00 \leq x \leq 0.50)$ ceramics were synthesized using the Sol-Gel technique. Slight shifts were observed in the XRD measurement in the $2 \theta$ positions to higher and lower angles with an increase in Li-doping. The average crystallite size was estimated based on comparative analysis using Scherer's equation and Williamson-Hall, mainly, regarding the size-strain plot. Scherer's crystallite size has the least values due to the neglect of strain contribution to crystallite size. A decrease in crystallite size was observed in all the samples, in addition to a general decrease in the unit cell volumes and bond lengths. EDS analysis showed that all the nominal elements were present with the presence of carbon, calcium, iron, chlorine as minor impurities due to their very low concentrations. Agglomeration, non-uniform distribution of grains and porous regions were observed with the grain size showing a decreasing trend with an increase in lithium concentration. The optimum doping in this work was at $\mathrm{x}=0.5$ which corresponds to the lowest grain size and thus has the potential for piezoelectric application.

\section{References}

[1] Corso D, Andrea P, Michel R, Raffaele BA. Ab initio study of piezoelectricity and spontaneous polarisation in ZnO. Physical Review. B, Condensed Matter. 1994; 50(15): 10715-10721. Available from: doi: 10.1103/ PhysRevB.50.10715.

[2] Dai SH, Park HS. Surface effect of piezoelectricity of $\mathrm{ZnO}$ nanowire. Journal of Mechanics and Physics of Solids. 2013; 61: 385-397.

[3] Wang X, Wu Z, Webb J. Ferroelectric and dielectric properties of Li-doped ZnO thin Films prepared by Pulsed laser deposition. Applied Physics A. 2003; 77: 561.

[4] Fan Z, Lu JG. Zinc oxide nanostructures: Synthesis and properties. Journal of Nanoscience and Nanotechnology. 2005; 5: 1561.

[5] Segets D, Gradl J, Taylor RK, Vassilev V, Peukert W. Analysis of optical absorbance spectra for the determination of $\mathrm{ZnO}$ nanoparticle size distribution, solubility, and surface energy. ACS Nano. 2009; 3: 1703-1710. Available from: doi: 10.1021/nn900223b.

[6] Bagnall DM, Chen YF, Zhu Z, Yao T. Optically pumped lasing of $\mathrm{ZnO}$ at room temperature. Applied Physics Letter. 1997; 70: 2230. Available from: doi: 10.1063/1.118824.

[7] Major S, Chopra KL. Indium-doped zinc oxide films as transparent electrodes for solar cells. Solar Energy Material. 1998; 17(5): 319.

[8] Ellmer K, Wendt R. D.c. and r.f. (reactive) magnetron sputtering of $\mathrm{ZnO}$ :Al films from metallic and ceramic targets: A comparative study. Surface Coating Technology. 1997; 93(1): 21.

[9] Klingshirn C. ZnO material physics and applications. Journal of Physical Chemistry. 2007; 8(6): 782-803. 
Available from: doi: $10.1002 \% 2 \mathrm{Fcphc} .200700002$.

[10] Özgüra Ü, Alivov Ya I, Liu C, Teke A, Reshchikov MA, Doğan S, Avrutin V, Cho S-J, Morkoç H. A comprehensive review of Zno materials and device. Journal of Applied Physics. 2005; 98(4): 041301. Available from: doi: 10.1063/1.1992666.

[11] Caglar M, Caglar Y, Aksoy S, Ilican S. Temperature dependence of the optical band gap and electrical conductivity of sol-gel derived undoped and Li-doped ZnO films. Applied Surface Science. 2010; 256(16): 4966-4971. Available from: doi: 10.1016/j.apsusc.2010.03.010.

[12] Prasad SE, Waechter DF, Richard GB, King HW, Yavuz Y. Elomas Thematics Conference on smart Structure and materials. 2005. p. 11. Available from: https://www.eccomas.org/2018/02/02/2005-thematic-conferences/ [Accessed 2nd November 2018].

[13] Mahato TH, Prasad GK, Acharya BSJ, Srivastava AR, Vijayaraghavan, R. Nanocrystalline zinc oxide for the decontamination of sarin. Journal of Hazard Material. 2009; 165(1-3): 928-932.

[14] Chaari M, Matouss A, Fakhfakh Z. Structural and dielectric properties of sintering Zinc oxide Bulk ceramic. Material Sciences and Application. 2011; 2: 764-769.

[15] Ardyanian M, Sedigh N. Heavy lithium-doped ZnO thin films prepared by spray pyrolysis method. Bulletin of Materials Science. 2014; 37: 1309-1314.

[16] Nam S, Sang-ji C, Jin-Hyo B. Physical properties of metal-doped Zinc oxide film for surface acoustic wave application. Nanoscale Research Letters. 2012; 7(1): 25. Available from: doi: 101186/1556-2767-25.

[17] Rajendran AR, Subramanian B. Structural, electrical, transport and opticalstudies of Li ion doped Zno nanostructures. Processing and Application of Ceramics. 2014; 8(1): 7-13.

[18] Abdolhossein S, Mohsen C, Ali GA, Aoun S. Effects of Li-Doping on morphological and optical properties of Zno nanostructures. Journal of Basic Applied Science Research. 2013; 3(1): 226-231.

[19] Taglient MA, Massaro N. Instrument methods. Journal of Applied Physics. 2008; 8: 123-134. Available from: doi: 10.1007/54009-614-0141.

[20] Saleem M, Fang L, Wakeel A, Rashad M, Kong CY. (2012). Simple preparation and characterization of Nano crystalline Zinc Oxide thin films by sol gel method on glass substrate. World Journal of Condensed Matter Physics. 2012; 2: 10-15. Available from: doi: 10.4236/wjcmp.2012.21002.

[21] Khan MKR, Rahman MM, Tanaka I. Preparation structural and electrical properties of $\mathrm{Zn}_{1-\mathrm{x}} \mathrm{Li}_{\mathrm{x}} \mathrm{O}$ solid solution. The Nucleus Journal. 2003; 39: 3-4, 149-154.

[22] Du YL, Deng Y, Zhang MS. Investigation of Li-induced structural disorder and phase transition in ZnO by Raman spectroscopy. Solid State Communications. 2006; 137(1-2): 78-81. Available from: doi: 10.1016/j.ssc.2005.10.002.

[23] Rakkesk RA, Balakumar S. Structural, electrical transport and optical studies of $\mathrm{Li}$ ion doped $\mathrm{ZnO}$ nanostructures. Processing and Application of ceramics. 2014; 8(1): 7-13.

[24] Lina YJ, Wang MS, Liu MS, Huanga HJ. Defects, stress and abnormal shift of the (002) diffraction peak for Li-doped Zno films. Applied Surface Science. 2010; 256(24): 7623-7627. Available from: doi: 10.1016/ j.apsusc.2010.06.016.

[25] Ardyanian M, Sedigh N. Heavy lithium-doped ZnO thin films prepared by spray pyrolysis method. Bulletin of Materials Science. 2014; 37(6): 1309-1314.

[26] Zeng YJ, Ye ZZ, Xu WZ. Investigation of the effect of Li-doping on electrical and dielectric properties of Zinc Oxide. Journal of Crystal Growth. 2005; 283: 180.

[27] Nayak PK, Jang J, Lee C, Hong Y. Electrical properties of activated Zinc oxide. Applied Physics Letter. 2009; 95: 193503.

[28] Suryanarayana C, Norton MG. X-ray Diffraction: A Practical Approach. New York: Plenum Press Publishing; 1998.

[29] Bindu P, Thomas S. Estimation of lattice strain in ZnO nanoparticles: X-ray peak profile analysis. Journal of Theoretical and Applied Physics. 2014; 8: 123-134.

[30] Ashour A, Kaid MA, El-Sayed N, Ibrahim AA. Physical properties of ZnO thin film deposited by spray pyrolysis technique. Applied Surface Science. 2006; 252(22): 7844-7848.

[31] Khalid M, Ziese M, Setzer A, Esquinazi P. Defect-induced magnetic order in pure Zno films. Physics Review B. 2009; 80(3): 035331. Available from: doi: 10.1103/PhysRevB.80.035331.

[32] Ahmadu U, Salaudeen IT. Structure, phase transition and impedance of $\mathrm{Zn}_{1-\mathrm{x}} \mathrm{Li}_{\mathrm{x}} \mathrm{O}(0.10 \leq x \leq 0.70)$ ceramic. Applied Physics A. 2006; 122(7): 10. Available from: doi: 10.1007/s00339-016 0213-6.

[33] Vojisavijevic K, Zunic M, Brankovic G, Sreckovic T. Electrical properties of mechanically acitivated Zinc oxide. Science of Sintering. 2006; 38: 131-138. Available from: doi: 10.2298/SOS0602131V. 
[34] Water W, Chu SY, Juan YD, Wu SJ. Dielectric and Piezoelectric properties of Lithium-doped Zno. Material Letter. 2002; 57: 998.

[35] Davood R, Taha R. The effect of heat treatment on the physical properties of sol-gel derived ZnO thin films. Applied Surface Science. 2009; 255: 5812-5817. Available from: doi: 10.1016/j.apsusc.2009.01.010.

[36] Park CH, Zhang SB, Wei SH. Origin of P-type doping difficulty in ZnO: The impurity perspective. Physical Review B. 2002; 66: 073202. Available from: doi: 10.1103/PhysRevB.66.073202.

[37] David AS, Hsu JWP. Effect of Lithium doping on microstructural and optical properties of ZnO nanocrystalline films prepared by sol-gel method. Nano Letters. 2018; 8(5): 228. Available from: doi: 10.1021/108074. 